\title{
Vračilo trošarine za kmetijsko in gozdarsko mehanizacijo
}

mag. Marjan Dolenšek, Gozdarski inštitut Slovenije, Oddelek za gozdno tehniko in ekonomiko

Objavljeno na spletu 12.01.2022 (https://doi.org/10.20315/IG.2022.0004)

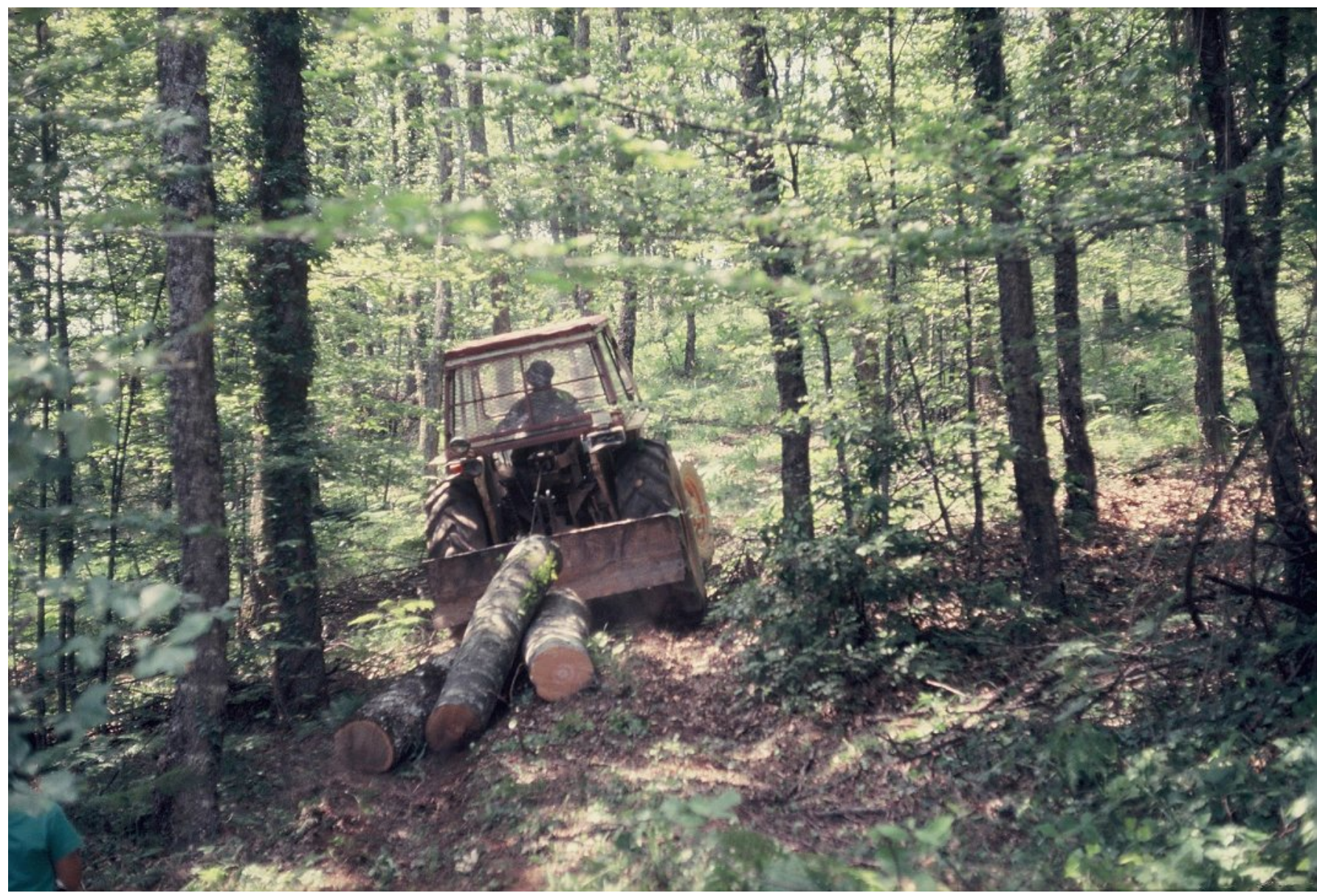

Vlaganje od 1. 1. 2022 le še elektronsko. »Nič ni v življenju tako zanesljivega kot spremembe«, tudi pri predpisih s katerimi v družbi urejamo medsebojne odnose, oz. prav pri predpisih. Ena izmed njih je tudi pri vlaganju zahtevkov za vračilo trošarine. Od 1. januarja 2022 je obvezno oz. je mogoče le še vlaganje zahtevkov v elektronski obliki.

Vračilo trošarine za energente porabljene za pogon kmetijske in gozdarske mehanizacije pri uporabi 
kmetijskih zemljišč in gozdov je mogoče zadnjih 20 let. Vlaganje zahtevkov za vračilo je eden najenostavnejših postopkov za različne vloge v kmetijstvu, ki so vezane na subvencije, olajšave, podpore itn. Zahtevek se izpolni na enostavnem obrazcu in pošlje na pristojni včasih carinski oz. sedaj finančni urad, doma pa 10 let shrani račune za porabljeno gorivo. Do sedaj so se zahtevki vlagali na papirnih obrazcih, zadnja tri leta pa je bilo mogoče tudi prostovoljno elektronsko vlaganje zahtevkov $v$ sistemu eCarine in do obveznega vlaganja v elektronski obliki je bil pričakovano le še korak.

Sredi letošnjega leta je Državni zbor sprejel spremembe Zakona o trošarinah (Uradni list RS, št. 92/21; ZTro-1A), ki so prinesle tudi obvezno vlaganje zahtevkov za vračilo trošarine v elektronski obliki za vse, ki uveljavljajo vračilo trošarine na podlagi Zakona o trošarine. To pa so tudi fizične osebe (kmetje, lastniki gozdov), ki vlagajo zahtevke za vračilo trošarine za energente, porabljene za kmetijsko in gozdarsko mehanizacijo na obrazcu TRO-A in pravne osebe, agrarne skupnosti ali samostojni podjetniki posamezniki, ki zahtevke vlagajo na obrazcu TRO-B. Zahtevek v elektronski obliki se po 1.1.2022 vloži tudi za vračila, ki se nanašajo na davčno obdobje leta 2021, oz. za porabljeno gorivo v letu 2021. Predviden je tudi nadomestni postopek, če informacijski sistem davčnega organa ne bi deloval. $V$ tem primeru bi bila informacija objavljena pred iztekom roka za vložitev in omogočena vložitev preko e-pošte ali v papirni obliki. Je pa navedeno le malo verjetno, saj so ti sistemi zelo robustni in zanesljivi.

Elektronski zahtevek za vračilo trošarine se vloži v informacijski sistem za predložitev dokumentov $\mathrm{S}$ področja trošarin (IS E-TROD), do njega pa se dostopa preko sistema eDavki. Na Finančni upravi RS so pripravili navodila za dostop in jih objavili v dokumentu z naslovom »Predložitev dokumentov $\mathrm{S}$ področja trošarin in okoljskih dajatev v elektronski obliki«, posebej pa so se potrudili in pripravili podrobna, pregledna in slikovno ilustrirana navodila za dostop do informacijskega sistema in samo vlaganje zahtevkov za fizične osebe, ki zahtevke vlagajo na obrazcu TRO-A. Dokumenta sta ločena za vlagatelje, ki do v sistem eDavki vstopajo z uporabniškim imenom in geslom in za tiste, ki vstopajo $\mathrm{s}$ kvalificiranim digitalnim potrdilom. Te dokumente je mogoče najti na spletnih straneh Finančne uprave, objavljeni pa so tudi na spletnih straneh Kmetijsko gozdarske zbornice in Strojnih krožkov, priloženi pa so tudi temu prispevku.
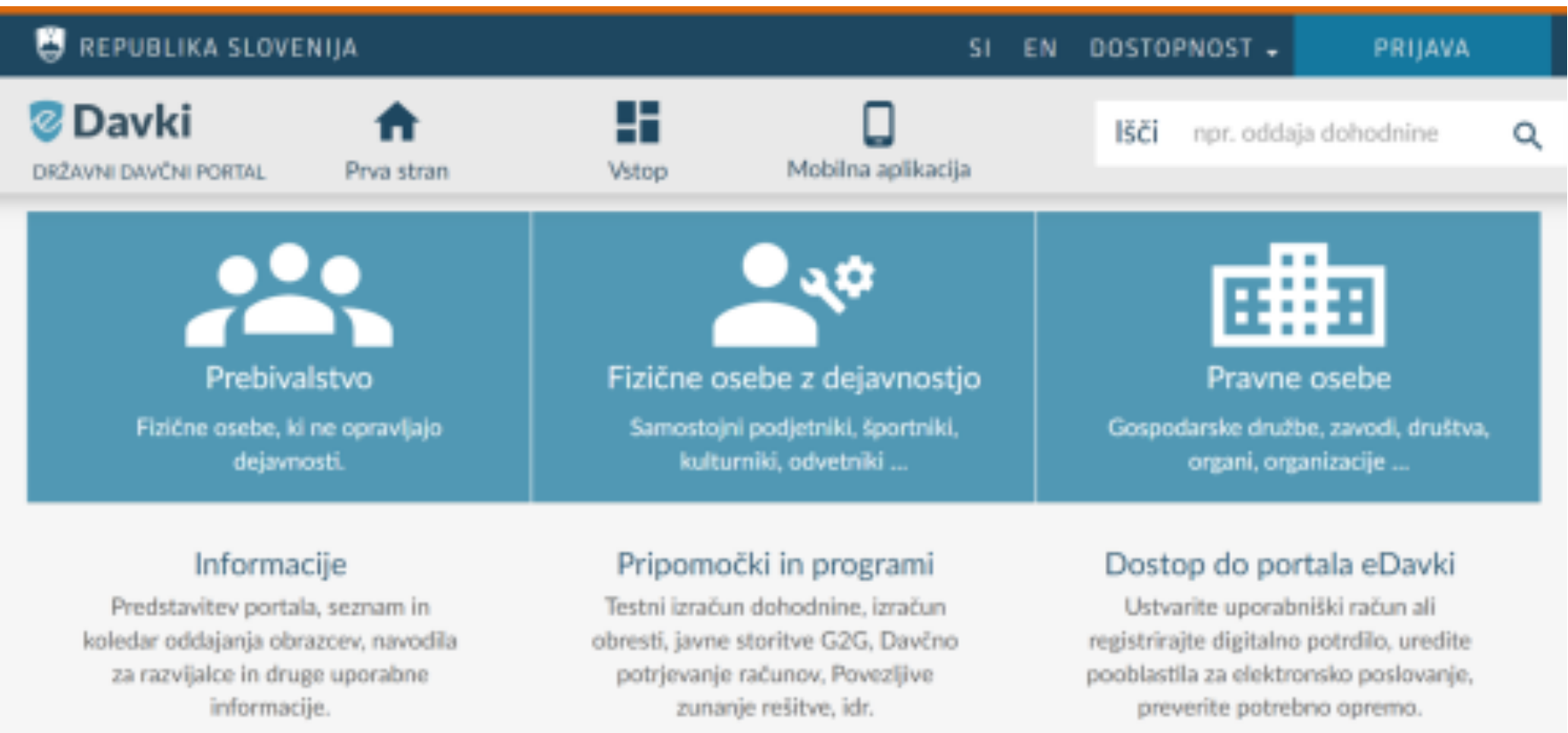

Dostop do portala eDavki

Ustvarite uporabniski račun ali

registriajte digitalne potrdila, uredite pooblastila za elektronsko poslovanje, preverite potrebno opremo. 
Po osebnem mnenju in izkušnjah z elektronskim vlaganjem zahtevkov za vračilo v zadnjih treh letih spodaj podpisanih, je informacijski sistem za trošarine strukturno, menijsko in grafično nekoliko manj prijazen do uporabnika kot sistem eDavki. Je pa to razumljivo, saj je nekaj starejše zasnove, a se $z$ navodili brez težav znajdemo in vložimo zahtevek z nekaj kliki in vpisi. Zato se vsi, ki uporabljate eDavke kar lotite poskusnega dostopa, saj sistem že deluje, po 1.1.2022 pa vložite zahtevek. Z veliko gotovostjo pa lahko pričakujemo, da se bo večina kmetov za vlaganje zahtevkov pooblastila druge, najpogosteje kmetijsko gozdarske zavode ali zadruge. Znano je, da za kar 25 tisoč kmetov od 30 tisoč, ki uveljavljajo pavšalno nadomestilo, elektronske obračune vlagajo navedeni pooblaščenci. Obrazec pooblastila ni predpisan, mora pa vsebovati vse podatke potrebne za pooblaščanje. Na Kmetijsko gozdarskem zavodu Ljubljana smo pripravili ustrezen obrazec, ki je na voljo na spletnih straneh zavoda, KGZS in strojnih krožkov, pa tudi na izpostavah Javne službe kmetijskega svetovanja. $\checkmark$ prilogi obrazca so navedeni tudi naslovi oddelkov za trošarino FURS za pošiljanje obrazca. Poudariti pa je potrebno, da je za vnos zahtevkov za vračilo trošarine navedeno pooblastilo potrebno izpolniti ne glede na to, če so vlagatelji pooblaščencem že dodelili pooblastilo za uporabo sistema eDavki v njihovem imenu.

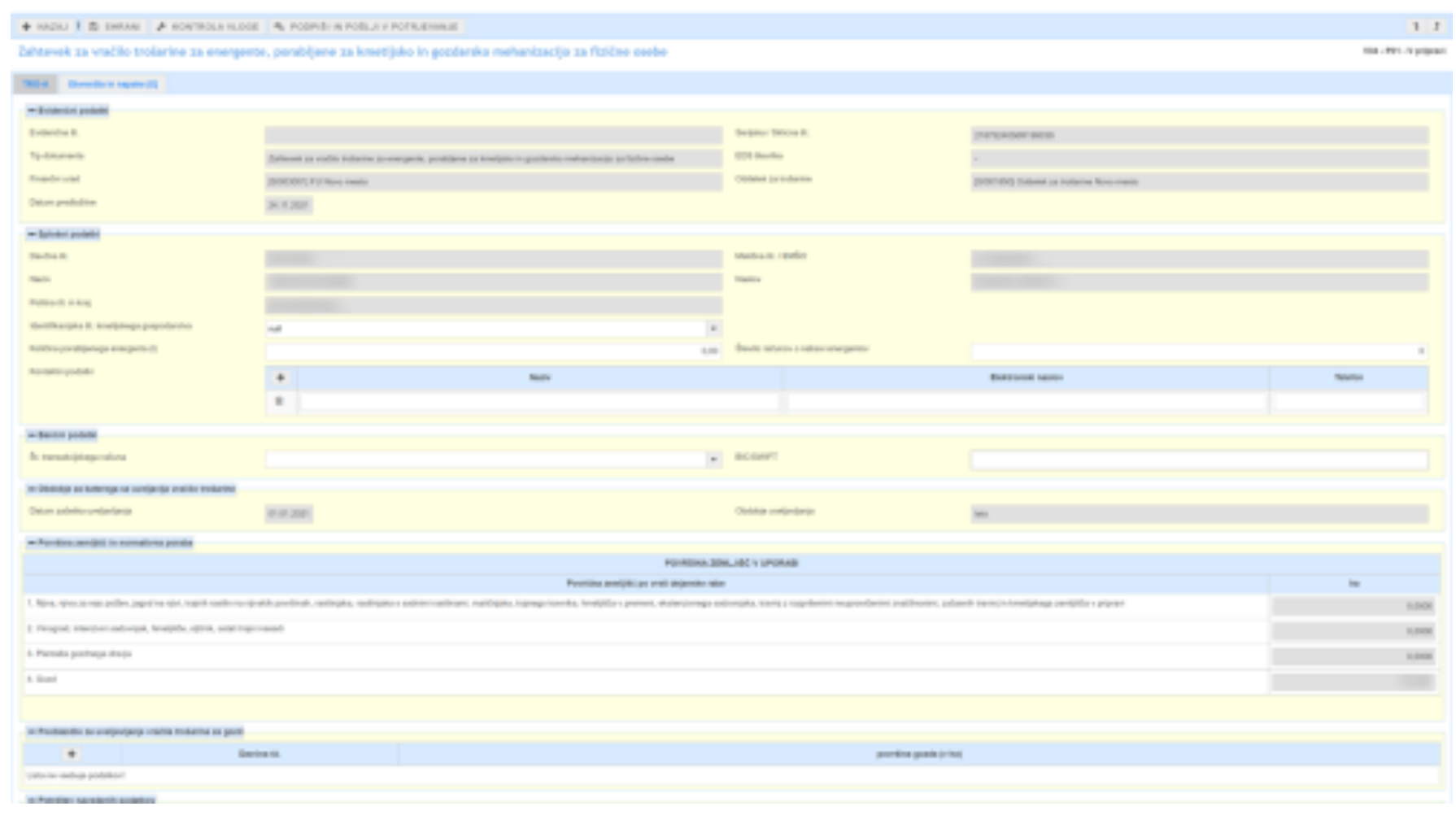

Elektronski obrazec TRO-A v informacijski sistem za predložitev dokumentov s področja trošarin pripravljen za izpolnjevanje za vračilo trošarine za leto 2021.

\section{Priloge:}

Dostop do portala $\quad$ e-davki $\quad$ s $\quad$ kvalificiranim potrdilom (https://lj.kgzs.si/Portals/1/A-Splet2021/Dostop_do_portala_eDavki_s_kvalificiranim_digitalni m_potrdilom_za_vloznike_zahtevka_za_vracilo_trosarine_za_kmetijsko_in_gozdarsko_mehanizacijo.pdf) Dostop do portala e-davki $z^{-}$uporabniškim imenom in 
geslom (https://lj.kgzs.si/Portals/1/A-Splet2021/Dostop_do_portala_eDavki_z_uporabniskim_imenom_in _geslom_za_vloznike_zahtevka_za_vracilo_trosarine_za_kmetijsko_in_gozdarsko_mehanizacijo.pdf) Informacijski_sistem_E_TROD_programska_podpora_trosarinam_in_okoljskim_dajatvam (https://lj.kgzs. si/Portals/ 1 / A -

Splet2021/Informacijski_sistem_E_TROD_programska_podpora_trosarinam_in_okoljskim_dajatvam.pdf) Pooblastilo

TRO-A -

tabela (https://lj.kgzs.si/Portals/1/A-Splet2022/Pooblastilo\%20e-vlaganje\%20povrnitev\%20trosarine-ta bela-forms\%201.pdf) 